\title{
Analysis of Junior High School Students Creative Thinking Skills in Distance Learning
}

\author{
Nisa Auliyah', Elok Sudibyo ${ }^{2}$, Munasir $^{3}$ \\ 1,2,3 State University of Surabaya, Surabaya, Indonesia
}

\begin{tabular}{|c|c|}
\hline (A) Check for updates open access (c) (i) (2) & DOI: $\underline{\text { https://doi.org/10.46245/ijorer.v2i3.111 }}$ \\
\hline Sections Info & ABSTRACT \\
\hline Article history: & Purpose of this study is to analyze the creative thinking skills of junior high \\
\hline Submitted: April 1, 2021 & school students in physics in distance learning. This study describes students' \\
\hline Final Revised: April 23, 2021 & creative thinking skills in physics using question instruments related to \\
\hline Accepted: May 17, 2021 & creative thinking. The method used in this research is descriptive quantitative \\
\hline Published Online: May 31, 2021 & method. The test is conducted online via google form. The instrument contains \\
\hline Keywords: & eight questions related to the physical matter of substance pressure and its \\
\hline Creative Thinking & application in everyday life. The subjects of this study were 32 students of VIII \\
\hline Distance Learning & Junior High School in Gresik. The results showed that the analysis related to \\
\hline Junior High School & students creative thinking ability in physics obtained an average of $51.5 \%$ \\
\hline Pressure Substance & which was included in the creative enough category. On the fluency indicator \\
\hline 21st century skills & it was $37 \%$ with the less creative category, $58 \%$ on the flexible thinking \\
\hline 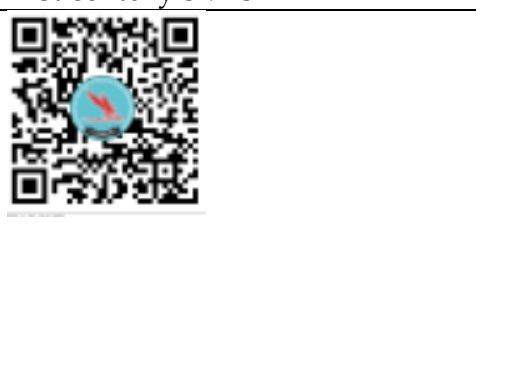 & $\begin{array}{l}\text { indicator (Flexibility). with the creative enough category, } 64 \% \text { on the original } \\
\text { thinking indicator (Originality) with the creative category, } 53 \% \text { on the detailed } \\
\text { thinking indicator (Elaboration) with the creative enough category and } 43 \% \text { on } \\
\text { the metaphorical thinking indicator (metaphorical thinking) with the creative } \\
\text { enough category. From these results it can be concluded that the creative } \\
\text { thinking skills of student's physics in distance learning are still in the } \\
\text { sufficient category so that it needs to be improved especially in distance } \\
\text { learning at this time, so that alternatives are needed in learning that is suitable } \\
\text { for distance learning. Creative thinking skills are one of the important skills to } \\
\text { be trained in the } 21 \text { st century today. }\end{array}$ \\
\hline
\end{tabular}

\section{INTRODUCTION}

The 21st century is called the century of knowledge, knowledge-based economy century, the century of information technology, globalization, the industrial revolution 4.0, and so on (Wayan, 2019). The life of the 21st century is related to the rapid and abundant development of information and the use of sophisticated technology, this has implications for education that education must be able to create adaptive graduates. (Dwi, 2019).

To be able to produce a creative, innovative and competitive generation, some skills in learning need to be trained in facing the 21st century. The main skills needed in the 21st century are Critical Thinking Skills, Communication Skills, Collaboration Skills and Creative Thinking Skills as a necessary competence in the 21st century known as the 4C competence (Partnership for 21st Century Learning, 2015).

The skills that students need to have are creative thinking skills (Dwi, 2019). Creative thinking is a thought process that generates a wide variety of possible ideas and ways (Tridaya, 2012). Creative thinking skills (Creative Thinking Skills) are skills related to the skills of using a new approach to solve a problem, innovation and discovery (Zubaidah, 2018). Creative thinking is the skill of discovering new things that did not exist before, 
being original, developing new solutions for each problem, and involving the ability to generate new, varied, and unique ideas (Leen et al., 2014).

In 2019 seems to be a difficult year because it is the first year for the emergence of the outbreak Coronavirus disease (Covid-19). The epidemic is a world health problem, especially in Indonesia. On January 30, 2020, WHO determined the Covid-19 pandemic as a Public Health Emergency of International Concern (PHEIC) or a public health emergency that is troubling the world and the increase in the number of Covid-19 patients is taking place very quickly and spreading throughout the world (Satiyasih, 2020).

During this pandemic, the delivery of education, in formal and informal activities, was shifted to online or online methods radically and massively. So that informants (teachers, lecturers, teachers, educators) as well as target information must be technology literate if they do not want to be left behind. This opinion is in line with ( Satiyasih, 2020) which states that in the education sector, teachers and students will be accustomed to interacting with the distance learning system.

Distance learning is a learning system that utilizes media that can allow interaction between teachers and learners (Giri, 2020). Distance learning relies on connectivity between students and teachers online by utilizing their own devices to connect with each other (Pakpahan, 2020). Distance learning is required to seek innovative ideas, ways, tools and substances in order to operate effectively and efficiently (Jalil, 2016).

The situation during a pandemic period requires people to carry out all activities within limitations. To overcome this, all activities are carried out at a distance. Many public places and various activities in them lead to closings, delays, or diversion of events into the realm of online distance (online) including educational institutions. Based on Circular No. 4 of 2020, it states that all face to face activities are converted into online/ online learning. This was done to reduce the transmission of the virus in the community (Perdana, 2020).

Basically physics is a natural science which consists of several aspects, including science as a product, process, scientific attitude and application. Science as a product is a collection of knowledge, science as a process is a way of investigation, while science as a scientific attitude is a mindset and Science as an application is an application of concepts that can manifest in a concrete form in the form of technology (Sunarno, 2018). So that science learning must be able to provide a role in forming the creative character of students as reliable successors in the future.

Based on the results of the study, information was obtained that the creative thinking abilities of physics students of class VIII-D Junior High School Xaverius Lubuklinggau City were still less creative (36.68\%) (Arini, 2017). In line with this research, the results showed that students creative thinking skills were quite low with an average percentage of $39.76 \%$. In detail, it can be described for each dimension of creative thinking skills in students Fluency, namely of 33.80\%, Originality of $38.43 \%$, Elaborate of $38.89 \%$, and Flexibility of $47.92 \%$ (Wahyu, 2016)

This study aims to analyze students creative thinking skills in distance learning physics. The function of conducting an analysis related to students creative thinking skills in distance learning is to find out learning innovations that can be used according to the needs of distance learning so that learning that takes place is still able to train students creative thinking needed in the 21st century even in a distance learning situation. far. Analysis is a process that begins with suspecting the truth, then 
investigates and describes what is the subject of the problem so that it can be translated into smaller parts after there is an appropriate assessment action to determine objectives (Arini, 2017).

\section{RESEARCH METHOD \\ General Background}

This research was conducted to analyze the creative thinking skills of the eighth grade junior high school students in Gresik in studying the physics of substance pressure material in distance learning. This study used a pre-experimental design with a one-shot case study design and a descriptive quantitative approach. Pre-experimental design is a design that includes only one group or class that is given pre and post-test (Sugiyono, 2014). Descriptive research is research that aims to describe a state or phenomenon as it is without manipulating the object of research (Sukmadinata, 2015).

\section{Sample / Participants / Group}

Participants in this study used a sample of 32 junior high school students in grade VIII in Gresik, East Java, Indonesia.

\section{Instrument and Procedures}

Instrument is a tool used by researchers to obtain research data. According to (Nurlaila, 2016) the research instrument is a facility used by researchers to collect data. In this study, the instrument used was a creative thinking skill test in the form of several questions or exercises in the form of an essay which was used to measure students creative thinking skills. The data collection procedure used in this study was to distribute instruments for creative thinking. The test used is in the form of an essay test consisting of eight essay questions on google form which refer to the creative thinking indicator, namely Fluency; Flexibility; Elaboration; Originality and Metaphorical Thinking. The essay test was chosen because it has advantages that it can be used to measure students higher abilities (Stankous, 2016). The Following is a flow chart in this study:

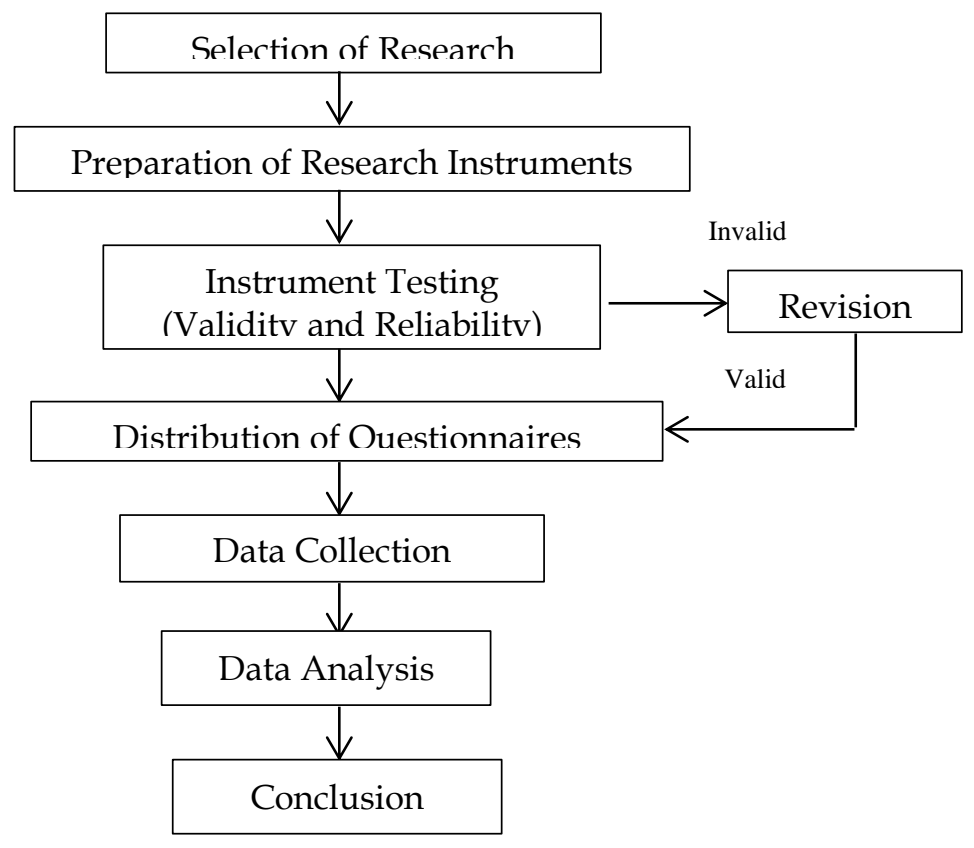

Figure 1. Flowchart of research procedure. 


\section{Data Analysis}

\section{Instrument Validity}

The way to calculate validity is calculated using the following formula:

$$
\mathrm{R}=\stackrel{s}{N} \times 100 \%
$$

Information:

Source: (Widoyoko, 2017)

$\mathrm{R}=$ Average score

$\mathrm{S}=$ Total score obtained

$\mathrm{N}=$ Maximum total score

After knowing the validity value of each expert, then combining the results of expert validity and analyzing all expert validators using the following formula:

$$
\mathrm{MR}=\frac{\sum R}{N}
$$

Source: (Sudijono, 2017)

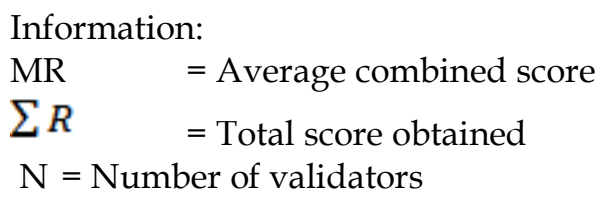

After calculating the validation value, then the validation results can be categorized as in the following table:

Table 1. Criteria for the validity.

\begin{tabular}{ll}
\multicolumn{1}{c}{ Coefficient } & Criteria \\
\hline $75 \leq \mathrm{VC} \leq 100$ & Very valid \\
$50 \leq \mathrm{VC}<75$ & Valid \\
$25 \leq \mathrm{VC}<50$ & Sufficiently Valid \\
$0 \leq \mathrm{VC}<25$ & Less Valid \\
\hline
\end{tabular}

\section{Instrument Reliability}

Source: (Riduwan, 2014)

Test used to determine the consistency or consistency of the test. According to (Arini \& Asista, 2017), the reliability test serves to determine the consistency of the test whether the test is reliable and remains consistent when used to retry. Reliability testing in this study was carried out using the Cronbach Alfa equation as follows:

$$
\mathrm{r}_{1}=\frac{K}{K-1}\left(1-\frac{\Sigma S i^{2}}{\Sigma S t^{2}}\right)
$$

(Liliasari, 2013)

$\begin{array}{ll}\text { Description } & : \\ \mathrm{r}_{1} & : \text { Reliability coefficient } \\ \mathrm{k} & : \text { Number of test items } \\ \mathrm{St}^{2} & : \text { Variance of total test } \\ \text { scores } \Sigma \mathrm{si}^{2} & : \text { Total variance of test items }\end{array}$


Conclusion of item reliability refers to the criteria for the reliability coefficient of the test with the standard formula $r_{11} 0.70$. If $r_{11} \geq 0.70$; then the questions being tested have high reliability. Conversely, if $\mathrm{r}_{11}<0.70$; then the questions tested have low or unreliable reliability (Wijaya, 2019). After calculating the reliability value, the results of the calculation are then categorized in the following table:

Table 2. Criteria for the level of reliability item.

\begin{tabular}{lll}
\hline \multicolumn{1}{c}{ Value Range } & Criteria \\
\hline$>0.800-1,000$ & High & \\
$>0.600-0.800$ & High enough & \\
$>0.400-0.600$ & Medium & \\
$>0.200-0.400$ & Low & \\
$0.000-0.200$ & Very low \\
\hline
\end{tabular}

Observation Results Data Creative Thinking Skills

(Sugiyono, 2012)

Data analysis technique results observation using a holistic scoring scale by giving a score of 1-4 on each question number, then calculating the percentage value of students creative thinking abilities on each indicator which is calculated using the following formula:

$$
\mathrm{NP}=\frac{R}{S M} \times 100 \%
$$

\footnotetext{
Description :

NP : Percentage value of creative thinking ability

$\mathrm{R} \quad$ : Raw score obtained by students

SM : Maximum score of observation
}

Next is changing the percentage value into categories, from the results of the data in the form of percentages will then be converted into categories. The references in changing presentation into categories can be explained as follows:

Table 3. Conversion percentage of creative thinking skills.

\begin{tabular}{cc}
\hline Percentage of & Categories \\
\hline $81 \%-100 \%$ & Very creative \\
$61 \%-80 \%$ & Creative \\
$41 \%-60 \%$ & Creative Enough \\
$21 \%-40 \%$ & Less Creative \\
$0 \%-20 \%$ & Not Creative \\
\hline
\end{tabular}

Source: (Modification of (Arini, 2017)

\section{RESULTS AND DISCUSSION}

Validation Instrument

In this study, the test instrument is validated by three experts. The results of the validation of this research instrument are that validator 1 gets a percentage of $92 \%$, validator 2 gets a percentage of $92 \%$ and validator 3 gets a percentage of $77 \%$. From the three validators, it was obtained a combined average score of 87 and was categorized 
as very valid. Following are the results of the validation of the research instrument statement:

Table 4. Results of the validity of the test instrument.

\begin{tabular}{lc}
\multicolumn{1}{c}{ Aspects Assessed } & Validation Results \\
\hline Matching items with indicators & Very Valid \\
Matching items with cognitive domains & Very Valid \\
Matching items with indicators of creative thinking skills. & Very Valid \\
Suitability of questions with education level. & Very Valid \\
Use of sentence formulations in the form of a clear question or command & Very Valid \\
sentence. & \\
Use of tables and figures related to the items. & Very Valid \\
The use of tables and figures has clear information. & Very Valid \\
Use of scoring guidelines in accordance with the items. & Very Valid \\
Formulation of communicative sentences. & Very Valid \\
The sentence uses good and correct language according to the rules of & Very Valid \\
writing. & \\
Variety of sentences do not lead to multiple interpretations. & Very Valid \\
Use common language or verbs according to EYD. & Very Valid \\
\hline
\end{tabular}

The validation of the instrument in this study was carried out by three junior high school science teachers. The results of the validation show that each aspect of the instrument has a very valid level of validity which can be seen in Table 4. A good quality test must meet the test requirements, namely validity, reliability, objectivity, practicality, and economic (Arikunto, 2013). Limitations in this study only use validity and reliability requirements. The test is said to be valid if the test can provide appropriate information and can be used to achieve certain goals (Oktanin, 2015). The validity of the items needs to be sought to find out which questions are not feasible and cause low validity (Utomo, 2018). Rationally, the validity of the questions can be seen in terms of the suitability of the contents of the questions with the material and indicators (Oktanin, 2015).

\section{Instrument Reliability}

Reliability test is used to determine the consistency or consistency of the test. According to (Arini, 2017) the reliability test serves to determine the consistency of the test whether the test is reliable and remains consistent when used to retry. The test is said to be reliable if the test produces consistent data whenever the test is carried out (Kusairi, 2013). The test is said to be reliable if the test will always give the same results if the test is given to the same group at different times or occasions (Oktanin, 2015).

Based on the calculation results, the reliability coefficient is 0.76 and it can be said that the instrument used in this study is reliable with a fairly high category. The criteria for the correlation coefficient range from $0.000-0.200$ are stated to have very low reliability, the coefficient of $\mathrm{r}$ ranges from 0.200 to 0.400 is declared to be low reliable, the range $0.400-0.600$ is stated to be moderate, the range $0.600-0.800$ is stated to be quite high, and the range $0.800-1.000$ is declared very high (Sugiyono, 2012). The conclusion of item reliability refers to the reliability coefficient criteria of the test with the standard formula $r_{11} 0.70$. If $r_{11} \geq 0.70$; then the questions being tested have high reliability. Conversely, if $\mathrm{r}_{11}<0.70$; then the questions tested have low or unreliable reliability (Wijaya, 2019). 
Analysis of Creative Thinking Skills

In this study, researchers developed instruments that refer to basic competencies, namely explaining substance pressure and its application in everyday life, including blood pressure, osmosis, and capillarity of the transport tissue in plants. The following are indicators of questions used by researchers in the preparation of instruments.

Table 5. Indicator questions on the instrument.

\begin{tabular}{ll}
\hline \multicolumn{1}{c}{ Sub material } & \multicolumn{1}{c}{ Indicator } \\
\hline Pressure Solid Substance & $\begin{array}{l}\text { Analyze the concept of pressure in living } \\
\text { things }\end{array}$ \\
& $\begin{array}{l}\text { Analyze the relationship between force and } \\
\text { surface area to the amount of pressure } \\
\text { appropriately }\end{array}$ \\
\hline Liquid Pressure & $\begin{array}{l}\text { Analyze the application of Archimedes' law } \\
\text { in everyday life } \\
-\end{array}$ \\
& $\begin{array}{l}\text { Analyze buoyancy } \\
\text { Analyze the application of Pascal's law in } \\
\text { everyday life }\end{array}$ \\
\hline Pressure & $-\begin{array}{l}\text { Gaseous Analyze the application of gaseous } \\
\text { pressure in everyday life }\end{array}$ \\
\hline $\begin{array}{l}\text { Application of the concept } \\
\text { of pressure to living things }\end{array}$ & $-\begin{array}{l}\text { Analyze the concept of pressure in living } \\
\text { things }\end{array}$ \\
\hline
\end{tabular}

The score of the students' creative thinking skills test was obtained by an average of $51.5 \%$ with a fairly creative category. The following is a graph of the distribution of students' physics test scores:

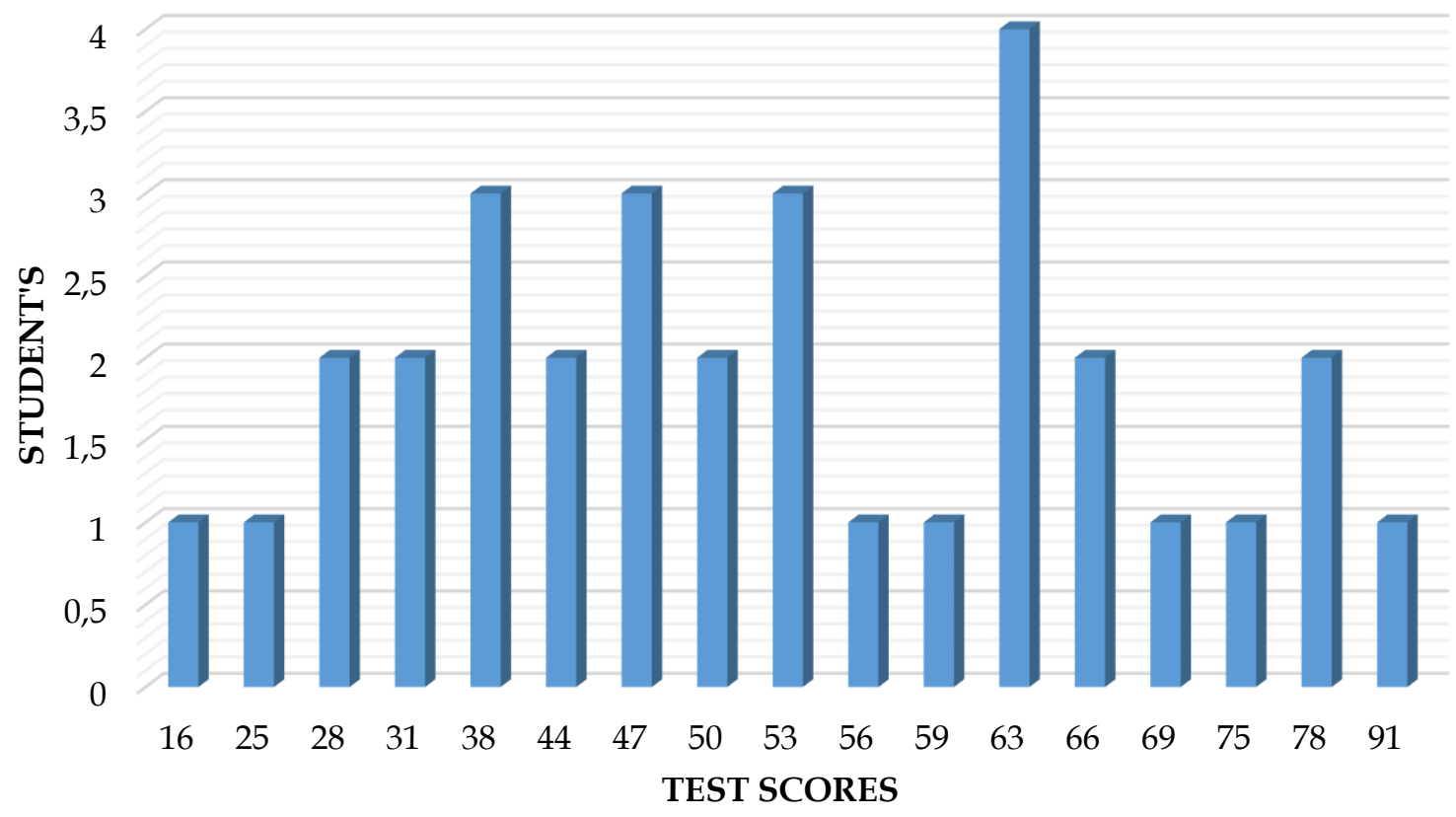

Figure 1. Creative thinking test scores. 
The results of the distribution of the student's physics test scores on the average of the highest scores obtained by students are 70, but these scores are not sufficient to meet the minimum criteria for junior high school science subjects. The minimum completeness criteria are set by the teacher board at a school (Permendikbud, 2016). Based on the teacher's interview in the field of science, it would be better if the average student had a minimum achievement of 72 so that students' creative thinking skills in physics were included in the category of needing improvement.

Creative thinking is the ability to provide various possible answers or solutions to problems and is able to spark many ideas or ideas (Yamin, 2013). Indicators of creative thinking used in the instrument namely Fluency (fluent thinking); Flexibility (flexible thinking); Originality (original thinking); Elaboration (detailed thinking) and Metaphorical Thinking (thinking metaphors). The following is the relationship between indicators of creative thinking skills and the test instrument.

Table 6. The relationship between indicators of creative thinking skills and indicators of questions.

\begin{tabular}{|c|c|}
\hline $\begin{array}{l}\text { Indicators of Creative } \\
\text { Thinking }\end{array}$ & Indicators of questions \\
\hline fluency (thinking fluently) & $\begin{array}{l}\text { - Analyzing the application of Pascal's law in everyday } \\
\text { life } \\
\text { - Analyzing the application of Archimedes law in } \\
\text { everyday life }\end{array}$ \\
\hline Flexibility (flexible thinking) & $\begin{array}{l}\text { - Analyzing the application of pressure in gaseous } \\
\text { substances in life } \\
\text { - Analyzing buoyancy }\end{array}$ \\
\hline Originality (original thinking) & $\begin{array}{l}\text { - Analyzing the relationship between force and surface } \\
\text { area to the amount of pressure }\end{array}$ \\
\hline Elaboration (detailed thinking) & $\begin{array}{l}\text { - Analyzing the relationship between force and surface } \\
\text { area to the amount of pressure }\end{array}$ \\
\hline $\begin{array}{l}\text { Metaphorical thinking (thinking } \\
\text { metaphorically) }\end{array}$ & $\begin{array}{l}\text { - Analyzing the concept of pressure in living things } \\
\text { - Explaining the definition of hydrostatic pressure }\end{array}$ \\
\hline
\end{tabular}

Data analysis of creative thinking skills was carried out by finding the average presentation of each indicator of creative thinking skills. The following in Figure 1 is the percentage result on each indicator of creative thinking skills.

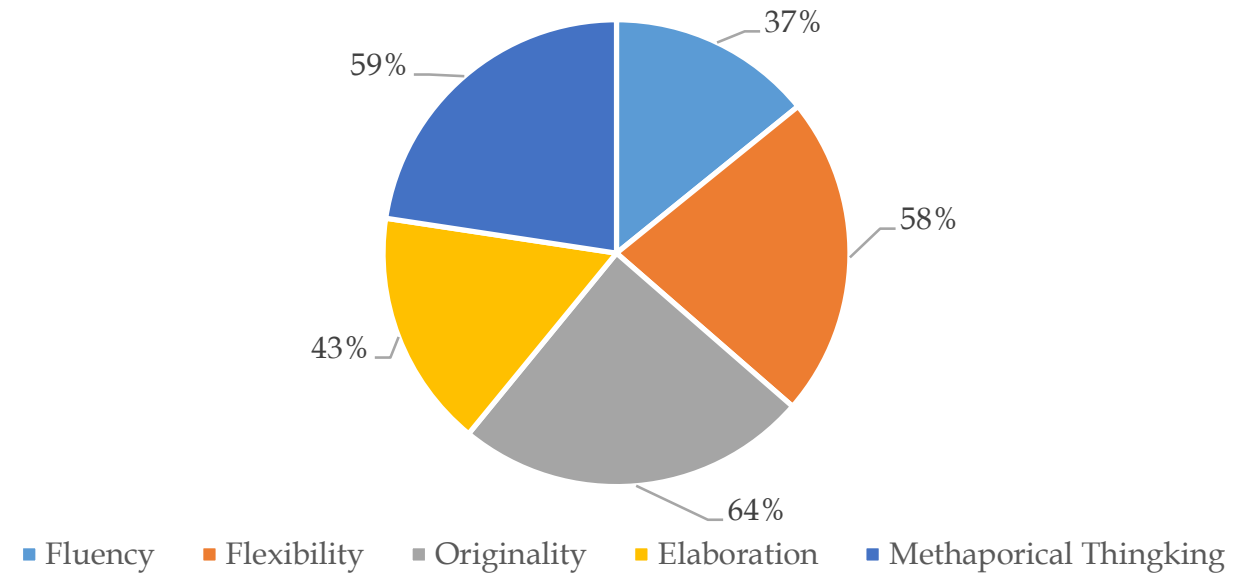

Figure 2. Average percentage of creative thinking skills indicators for each indicator. 
After determining the percentage of each indicator of creative thinking skills, then the next step is to determine the category of students' creative thinking skills. The following Table 7 presents the categories of creative thinking skills on each indicator of creative thinking.

Table 7. Category of indicators for creative thinking skills.

\begin{tabular}{lcl}
\hline \multicolumn{1}{c}{ Indicators of creative thinking skills } & Percentage (\%) & Criteria for \\
\hline fluency (thinking fluently) & 37 & Less creative \\
\hline Flexibility (thinking flexibly) & 58 & Quite creative \\
\hline Originality (original thinking) & 64 & Creative \\
\hline Elaboration (detailed thinking) & 43 & Quite creative \\
\hline Metaphorical Thinking (thinking metaphors) & 59 & Quite creative. \\
\hline
\end{tabular}

From the research results, the students creative thinking skills in physics were obtained in each indicator, namely, the indicator fluency (thinking fluently), which was $37 \%$ with the less creative category; on the indicator flexibility (flexible thinking), which is $58 \%$ with a fairly creative category; on the indicator originality (original thinking), which is $64 \%$ in the creative category; the indicator elaboration (detailed thinking) is $43 \%$ with a fairly creative category; on the indicator metaphorical thinking (thinking metaphor) which is $59 \%$ with the category quite creative. The following is a table of the percentage of creative thinking skills for each number of test questions.

Table 8. Percentage of creative thinking skills criteria for each question.

\begin{tabular}{cccc}
\hline Creative thinking indicator & Number of test questions & Percentage (\%) & Criteria \\
\hline Fluency & 5 & 37 & Less creative \\
& 6 & 37 & Less creative \\
\hline Flexibility & 2 & 63 & Creative \\
& 4 & 50 & Self-creative \\
\hline Originality & 1 & 65 & Creative \\
\hline Elaboration & 7 & 43 & Quite creative \\
\hline Metaphorical Thinking & 3 & 52 & Enough \\
& 8 & 66 & Creative \\
\hline
\end{tabular}

Based on the results obtained, fluency in numbers 5 and 6 got a percentage of $37 \%$ and $37 \%$ which are included in the less creative criteria, meaning that most students are less able to solve physics description questions on the pressure material. substance.

According to (Rahmazatullaili et al., 2017) states that thinking fluently is an ability to generate many ideas/ ideas. Thinking skills fluency in According to Torrance in (Susanto, 2014) is the ability to generate ideas. Seeing the lack of skills of fluency students, teachers need to improve students' creative thinking skills on this indicator. Things that teachers can do in improving fluency thinking skills are creating lessons that encourage students to create or think about many ideas. According to (Arini, 2017) to improve students fluent thinking skills, at every meeting the teacher tries to encourage students to come up with many ideas, answers, problem solving or questions so that students fluent thinking skills can develop.

Thinking skills (Flexibility) contained in questions number 2 and 4 get a percentage of $63 \%$ in the creative category and $50 \%$ in the fairly creative category. From these results it can be seen that the students' flexible thinking skills are good enough. Flexible 
thinking skills are when students are able to think of more than one idea in solving problems (Prasetiyo, 2014). Dexterity think (Flexibility), the ability to produce a number of ideas, answers or questions varied, can see a problem from the viewpoint of different, look for alternatives or directions are different, and can use a variety of approach or way of thinking. Creative people are flexible in their thinking. They can easily abandon old ways of thinking and replace them with new ones. Flexible thinking skills are the ability to present various kinds of problem solving (Rahmazatullaili et al., 2017).

Original thinking skills (Originality) contained in question number 1 got a percentage of $65 \%$ in the creative category. From these results, it can be seen that the students' original thinking skills are good. Original thinking skills are the ability to have new ideas to solve problems (Susanto, 2014). Original thinking is the ability to express ideas or solve problems in ways that other people do not think (Armandita et al., 2017). This can be formed when students' knowledge is broader, so the more likely it is to generate new ideas or ideas that are not used by the general public (Mustika, 2013).

Skills Elaboration in question number 7 get a percentage of $43 \%$ with a fairly creative category. From the results it can be seen that the detailed thinking skills still need to be improved by the teacher. The ability to elaborate is a person's ability to describe a simple matter into a broader definition (Prasetiyo, 2014). Detailing skills are skills in developing, adding, developing an idea and expanding an idea (Arini, 2017)

Metaphorical thinking skills (Metaphorical thinking) contained in questions 3 and 8 get a percentage of $52 \%$ with a fairly creative category and $66 \%$ with a creative category. From these results, it can be seen that the students' skills in thinking metaphors are quite good. Metaphorical thinking is the ability to use comparisons or analogies to make new connections. Metaphor is a tool for conceptualizing and understanding something abstract into something creative (Nurhikmayati, 2017). The characteristics of the ability to think creatively according to (Azhari, 2013), among others, the indicators of thinking skills (Fluency) have the following characteristics: 1) produces many relevant ideas/ answers, 2) produces learning motivation, 3) has a flow of thoughts that smooth. The indicators of flexible thinking skills (Flexibility) have the following characteristics: 1 ) producing uniform ideas, 2) being able to change ways or approaches, 3) having different thoughts. The indicators of original thinking skills (Originality) have the following characteristics: 1) giving unusual answers, 2) giving answers other than others, 3) giving answers that people rarely give. The indicators of detailed thinking skills (Elaboration) have the following characteristics: 1) developing, adding, enriching an idea, 2) detailing the details, 3) expanding an idea. Metaphorical thinking (Metaphorical Thinking) an activity that refers to an activity to change a material from one meaning to another (Sunito, 2013).

Physics has an important role in various scientific disciplines, therefore it is necessary to integrate creative thinking skills in science subjects (Arini, 2017). To develop creative thinking, students need to be given opportunities for creative learning. Educators should be able to stimulate children to involve themselves in creative activities, by helping to find the necessary infrastructure. In this case what is important is to give freedom to children to express themselves creatively, of course, on condition that they do not harm other people or the environment. 


\section{CONCLUSIONS}

Based on the research results, it can be concluded that in general students creative thinking skills are categorized as quite creative. The five indicators of creative thinking skills, the indicators flexibility and metaphorical thinking can be said to be good, but for indicators fluency; originality; elaboration is said to be not good enough. The limitation of the sample in this study is that it only uses schools in one city. For further research, it can be developed by using several schools in more than one city in order to know students' creative thinking skills in physics more broadly. With this research, it is hoped that educators can find out the extent of junior high school students creative thinking skills in distance learning. So that the results of this analysis can be used as a consideration for educators to create a creative learning environment. This can be done by using an appropriate learning model or media to stimulate students' creative thinking skills, especially in current distance learning.

\section{REFERENCES}

Arikunto, S. (2013). Prosedur penelitian: Suatu pendekatan praktik. Jakarta: Rineka Cipta.

Arini, W \& Asista, A. (2017). Analisis kemampuan berpikir kreatif pada materi cahaya siswa kelas VIII SMP Xaverius Kota Lubuklinggau. Science and Physics Education, 1(1), 23-38. DOI: $10.31539 /$ spej.v1i1.41.

Armandita, P., Eko, W., Lintang, R., Anisma, S., \& Samanta, R. (2017). Analisis Kemampuan berpikir kreatif pembelajaran fisika XI MIA 3 SMA Negeri Kota Jambi. Jurnal Penelitian Ilmu Pendidikan, 10(2), 129-135. https://doi.org/10.21831/jpipfip.v10i2.17906.

Azhari. (2013). Peningkatan Kemampuan berpikir kreatif matematik siswa melalui pendekatan kontruktivisme di kelas VII Sekolah Menengah Pertama (SMP) Negeri 2 Banyuasin III. Jurnal Pendidikan Matematika, 8(1), 1-12. https:// doi.org/10.15294/ujme.v8i1.25263.

Dwi, Y., D. \& S. (2019). Instrumen penilaian berpikir kreatif pada pendidikan abad 21. Jurnal Cakrawala Pendas, 5(2), 58-64. https://doi.org/Doi: 10.31949 / jcp.v5i2.1350.

Giri, A., et al. (2020). Efektifitas pembelajaran jarak jauh terhadap pembelajaran siswa di SDIT cendekia purwakarta. Jurnal Pendidikan Dasar, 11(1), 94-101. https://doi.org/doi.org/10.21009/JPD.011.10

Hidayati, F. (2010). Peningkatan kreativitas siswa pada pembelajaran matematika dengan pokok bahasan bangun ruang sisi datar (BRSD) di Kelas VIII SMP N 1 Tegalrejo. Yogyakarta: Jurusan FMIPA Universitas Negeri Yogyakarta.

Jalil, A. (2016). Pendidikan jarak jauh. Jurnal Ilmu Pendidikan, 1(1), 22-43. https:/ / doi.org/10.17977 / jip.v1i1.2257

Kusairi, S. (2013). Assesmen pembelajaran sains. Malang: UM Press.

Leen, C.C., Hong, K.F.F.H., dan Ying, T.W. (2014). Creative and critical thinking in Singapore Schools. Singapore: Nanyang Technological University.

Liliasari, M. (2013). Berpikir kompleks dan implementasinya dalam pembelajaran IPA. Makassar: Universitas Negeri Makassar.

Mustika. (2013). Analisis Kemampuan berpikir kreatif siswa SMP dalam pembelajaran pendidikan teknologi dasar (PTD). Jurnal Pengajaran MIPA, 18(1), 60-88.

Nurhikmayati. (2017). Pembelajaran dengan pendekatan methaporical thinking untuk meningkatkan kemampuan pemahaman dan penalaran matematis siswa SMP. Jurnal THEOREMS (The Original Research of Mathematics), 1(2), 42-50.

Nurlaila, Tawil, M., \& Haris, A. (2016). Analisis keterampilan berpikir kreatif fisika pada peserta didik kelas IX IPA SMA Negeri 2 Bua Ponrang. Jurnal Pendidikan Fisika Universitas Muhammadiyah Makassar, 4(1), 127-143.

Oktanin, W. \& S. (2015). Analisis Butir Soal Ujian Akhir Mata Pelajaran Ekonomi Akuntansi. Jurnal Pendidikan Akuntansi Indonesia, 13(1), 35-44. 
Pakpahan, R., \& Fitriani, Y. (2020). Analisa Pemanfaatan teknologi informasi dalam pembelajaran jarak jauh di tengah pandemi virus corona COVID-19. Journal of Information System, Applied, Management, Accounting and Research, 4(2), 30-36.

Partnership for 21st Century Learning. (2015). P21 Framework Definition. [On line]. http://www.p21.org/storage/documents/docs/P21_Framework_Definitions_ New_Logo_2015.pdf

Perdana, N. R. (2020). Memberdayakan pendidikan di masa pandemi COVID-19 (Studi Kasus Refleksi Pembelajaran Jarak Jauh oleh Para Pelajar). Universitas Indonesia. https://doi.org/10.13140/RG.2.2.16935.78241

Permendikbud. (2016). Peraturan menteri pendidikan dan kebudayaan republik indonesia no. 20 tahun 2016 tentang standar kompetensi lulusan pendidikan dasar dan menengah. Jakarta: Menteri Pendidikan Republik Indonesia.

Prasetiyo, AD, Mubarokah, L., Pos, JJK, \& Sidoarjo, K. (2014). Berpikir kreatif siswa dalam penerapan model pembelajaran berdasar masalah matematika. Jurnal Pendidikan Matematika STKIP PGRI Sidoarjo, 2(1), 71-82.

Purwanto, N. (2013). Evaluasi hasil belajar. Yogyakarta: Pustaka Belajar.

Rahmazatullaili., Cut, M.Z., Said, M. 2017. Kemampuan berpikir kreatif dan pemecahan masalah siswa melalui penerapan model project based learning. Jurnal Tadris Matematika, 10(2), 166-183.

Riduwan. (2014). Dasar-dasar Statistika. Bandung: Alfabeta.

Satiyasih, E. (2020). Aktifitas Pembelajaran daring pada masa pandemi covid-19 di jurusan pendidikan geografi universitas siliwangi Tasikmalaya. Geography Science Education Journal (GEOSEE), 1(1), 21-30.

Stankous, N. (2016). Constructive response Vs. Multiple-Choice tests in math. American Experience and Discussion. European Scientific Journal, 306-316

Sudijono, A. (2017). Pengantar statistik pendidikan. Jakarta: PT Raja Grafindo Persada.

Sugiyono. (2012). Statistika untuk Penelitian. Bandung: Alfabeta.

Sugiyono. (2014). Metode penelitian pendidikan pendekatan kuantitatif, kualitatif, dan RED. Bandung: Alfabeta.

Sukmadinata, N. (2015). Metode penelitian pendidikan. Bandung: Remaja Rosdakarya.

Sunarno, W. (2018). Pembelajaran IPA di era revolusi industri 4.0. Seminar Nasional Pendidikan Fisika IV 2018.

Sunito. (2013). Methaporming. Jakarta: Indeks.

Susanto, A. (2012). Teori belajar dan pembelajaran. Jakarta: Kencana Prenada Media Group.

Susanto, A. (2014). Teori belajar dan pembelajaran. Jakarta: Kencana Prenada Media Group.

Tridaya, TP, Irwan \& Vionanda, D. (2012). Meningkatkan Kemampuan berpikir kreatif siswa dengan pembelajaran berbasis masalah. Jurnal Pendidikan Matematika, 1(1), 22-26.

Utomo, B. (2018). Analisis Validitas isi butir soal sebagai salah satu upaya peningkatan kualitas pembelajaran di madrasah berbasis nilai-nilai islam. Jurnal Pendidikan Matematika, 1(2), $145-159$.

Wahyu, S. (2016). Analisis keterampilan berpikir kreatif siswa SMA pada materi fluida statis. Jurnal Pembelajaran Fisika, 4(5), 307-317.

Wayan, I. (2019). Mengembangkan Keterampilan abad ke-21 dalam pembelajaran kimia. Jurnal Inovasi Pendidikan Kimia, 13(1), 2239-2253.

Widoyoko, E. (2017). Teknik penyusunan instrumen penelitian. Yogyakarta: Pustaka Pelajar.

Wijaya, I. \& D. (2019). Analisis Butir soal ujian akhir semester mata kuliah mapel SD matematika I tahun akademik 2018/2019. Jurnal Pendidikan Dasar, 7(1), 103-107.

Yamin, M. (2013). Strategi dan Metode dalam model pembelajaran. Jakarta: Referensi. 


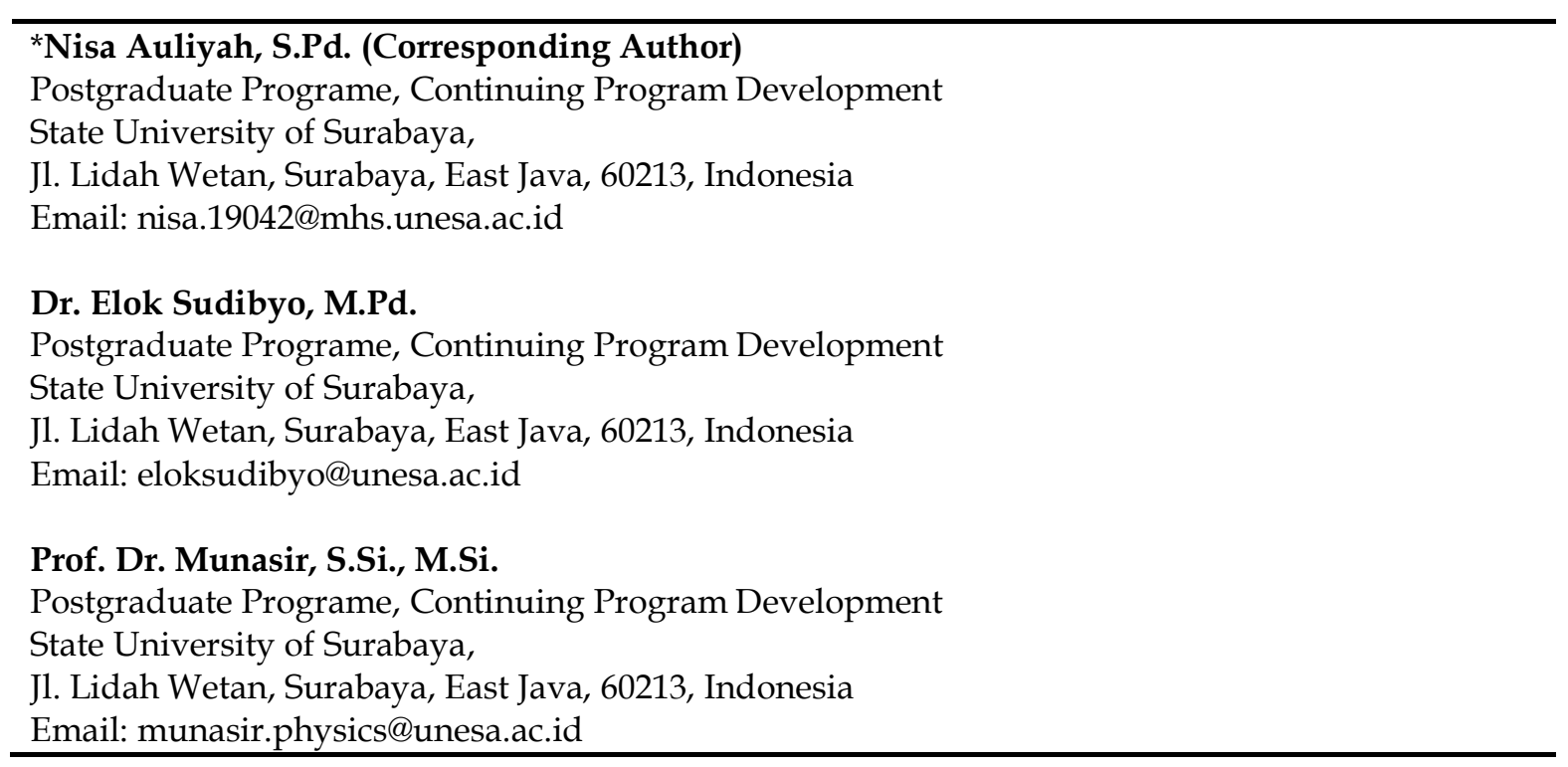

